\title{
ERRATUM
}

Beom Soo Kim $\cdot$ Seung Chul Lee $\cdot$ Sang Yup Lee

Yong Keun Chang · Ho Nam Chang

\section{High cell density fed-batch cultivation of Escherichia coli using exponential feeding combined with pH-stat}

Published online: 29 April 2004

(C) Springer-Verlag 2004

\section{Bioprocess Biosyst Eng (2004) 26: 147-150}

Due to an unfortunate error, the addresses of the authors were incomplete and are published correct here.

The online version of the original article can be found at http:// dx.doi.org/10.1007/s00449-003-0347-8

B. S. Kim $(\bowtie)$

Department of Chemical Engineering,

Chungbuk National University,

Cheongju, 361-763, Korea

E-mail: bskim@chungbuk.ac.kr

S. C. Lee

Hyundai Engineering and Construction Co.,

Seoul, 110-793, Korea

S. Y. Lee $\cdot$ Y. K. Chang $\cdot$ H. N. Chang

Department of Chemical and Biomolecular Engineering,

Korea Advanced Institute of Science and Technology,

Daejeon, 305-701, Korea 